\title{
Analisis Usahatani dan Saluran Pemasaran Biji Kakao di Kecamatan Juhar Kabupaten Karo Provinsi Sumatera Utara
}

\section{The Analysis of Farming and Cocoa Beans Marketing Channels in Juhar District, Karo Regency, North Sumatra Province}

\author{
Meri Juli Antri Sianturi1), Zulkarnain Lubis'2), Tumpal H.S. Siregar2) \\ 1) Magister Agribisnis, Pascasarjana, Universitasitas Medan Area, Indonesia \\ 2) Magister Agribisnis, Pascasarjana, Universitas Medan Area, Indonesia
} \begin{abstract}
Abstrak
Penelitian ini bertujuan untuk (1) Mengetahui unsur biaya usahatani; (2) Mengetahui kelayakan finansial usahatani kakao melalui analisis B/C ratio dan R/C ratio; (3) Mengetahui struktur biaya usahatani; (4) Menganalisis pendapatan dan Penerimaan petani kakao (5) Mengetahui sistem saluran pemasaran biji kakao; (6) Mengetahui biaya, keuntungan, marjin dan efisiensi pemasaran dimasing-masing lembaga pemasaran, serta besar farmer's share yang didapatkan oleh petani kakao di Kecamatan Juhar, Kabupaten Karo. Penentuan lokasi penelitian dilakukan dengan metode "Purposive Sampling". Pengambilan sampel dilakukan dengan judgment sampling sedangkan penentuan pedagang yang dijadikan sampel dilakukan dengan metode snowball sampling. Metode penelitian yang digunakan dalam penelitian yaitu metode survey dengan melaksanakan wawancara dan observasi kepetani dan pedagang. Hasil penelitian ini menunjukkan (1) Biaya usahatani meliputi tenaga kerja, pupuk dan pestisida (obat-obatan); (2) Hasil B/C ratio dan R/C ratio Desa Kidupen, Juhar Perangin-angin dan Juhar Ginting lebih besar dari 1, sehingga usahatani tersebut dapat diusahakan kerana memberikan keuntungan bagi petani. (3) Biaya usahatani kakao dibagi menjadi dua yaitu :a).Biaya tetap dan biaya tidak tetap. Biaya tetap (TFC) terdiri dari tenaga kerja, sedangkan biaya tidak tetap (biaya variabel/VC) terdiri dari pupuk dan pestisida (obat-obatan). (4) Rata - rata pendapatan petani kakao sebesar Rp.1.101.500 per bulan. (5) Pemasaran biji kakao di Kecamatan Juhar terdapat tiga tipe saluran pemasaran. Tipe pemasaran 1; Petani $\rightarrow$ Pedagang tingkat desa $\rightarrow$ Pedagang tingkat kecamatan $\rightarrow$ Pedagang tingkat provinsi. Tipe pemasaran 2; Petani $\rightarrow$ Pedagang tingkat kecamatan $\rightarrow$ Pedagang tingkat provinsi. Tipe pemasaran 3: Petani $\rightarrow$ Pedagang tingkat desa $\rightarrow$ Pedagang tingkat provinsi; (6) Biaya, keuntungan dan marjin pemasaran yang terbesar diperoleh pada tipe pemasaran satu yakni sebesar Rp.2.338; Rp.3.586 dan Rp.5.924 per kilogram. Efisensi pemasaran yang paling efisien pada tipe pemasaran 3 yakni sebesar 4,2\%. Semakin besar bagian harga yang diterima oleh petani, dapat dikatakan bahwa saluran pemasaran tersebut semakin efisien. Dengan demikian maka saluran pemasaran yang paling efisien adalah saluran pemasaran tiga.

Kata kunci : Biaya Usahatani, Pendapatan Petani, Pemasaran Kakao
\end{abstract}

\begin{abstract}
This study aims to (1) Know the cost elements of farming; (2) To know the financial feasibility of cocoa farming through analysis of B/C ratio and R/C ratio; (3) to know the cost structure of farming; (4) Analyzing the acceptance and income of cocoa farmers (5) Knowing the cocoa bean marketing system; (6) Knowing the cost, profit, margin and marketing efficiency of each marketing agencies, as well as the large farmer's share obtained by cocoa farmers in Kecamatan Juhar, Karo District. Determination of location of research conducted by the method of "Purposive Sampling". Sampling conducted by judgment sampling, while the determination of merchant that made the sample was done by snowball sampling method. The research method used in this research is survey method by conducted interviews and observation of fishermen and traders. The results of this study are 1) The cost of farming cover of labor, fertilizers and pesticides. (2) The result of $B / C$ and $R / C$ ratio is greater than one, so farming can be cultivated because it gives benefits for farmers. (3) The cost of cocoa farming is divided into two, namely: a) Fixed costs and non-fixed costs. The fixed cost (TFC) consists of labor, while the variable cost (VC) consists of fertilizers and pesticides. (4) Average income of cocoa farmers is Rp.13.280.000 per year or equivalent to Rp.1.101.500 per month. (5) Cocoa beans marketing in Juhar Subdistrict there are three types of marketing channels. Marketing channel 1 is Farmers $\rightarrow$ Village traders $\rightarrow$ Sub-district traders $\rightarrow$ Traders at provincial level. The types of marketing channel II is Farmers $\rightarrow$ Sub-district traders $\rightarrow$ Traders at the provincial level. The marketing channel III is Farmers $\rightarrow$ Village traders $\rightarrow$ Traders at provincial level. (6) The largest costs, benefits and margins obtained marketing by tipe of one marketing is Rp.2.338; Rp.3.586 dan Rp.5.924 The marketing efficiency is tipe of three marketing yi $4,2 \%$. The bigger the share of the price received by farmers, it can be said that the marketing channel is more efficient. Thus the most efficient marketing channel is the three marketing channels.

Keywords: Farming Costs, Farmers Income, Cocoa Marketing
\end{abstract}

How to Cite: Sianturi, M. J. A., Z. Lubis, \& T. H. S. SIregar. (2020). Analisis Usahatani dan Saluran Pemasaran Biji Kakao di Kecamatan Juhar Kabupaten Karo Provinsi Sumatera Utara. Jurnal Ilmiah Magister Agribisnis, 2(2) 2020: 181-193,

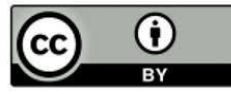


Meri Juli Antri Sianturi, Zulkarnain Lubis \& Tumpal H.S. Siregar. Analisis Usahatani dan Saluran Pemasaran Biji Kakao di Kecamatan Juhar Kabupaten Karo Provinsi Sumatera Utara.

\section{PENDAHULUAN}

Indonesia merupakan negara penghasil kakao terbesar ke-3 dunia setelah Pantai Gading dan Ghana. Jika ditinjau dari segi produktivitas, Indonesia masih berada di bawah produktivitas rata-rata negara lain penghasil kakao, sedangkan dari segi kualitas, kakao Indonesia tidak kalah dengan kakao dunia, dengan adanya perlakukan fermentasi yang baik akan dapat mencapai cita rasa setara dengan kakao yang berasal dari Ghana. Kakao Indonesia mempunyai kelebihan yaitu tidak mudah meleleh sehingga cocok bila dipakai untuk blending. Dengan keunggulan tersebut, peluang pasar kakao Indonesia cukup terbuka baik ekspor maupun kebutuhan dalam negeri. Dengan kata lain, potensi untuk menggunakan industri kakao sebagai salah satu pendorong pertumbuhan dan distribusi pendapatan cukup terbuka (Departemen Perindustrian dan Perdagangan, 2007).

Meskipun demikian, agribisnis kakao Indonesia masih menghadapi berbagai masalah kompleks dari sektor hulu hingga hilir. Beberapa masalah di sektor hulu antara lain produktivitas tanaman masih rendah, tingginya serangan hama dan penyakit serta sumber daya manusia yang masih rendah. Sebagian besar petani kakao hanya mendapatkan keahlian bercocok tanam kakao yang diwariskan dari pendahulu mereka dan masih bersifat tradisional sehingga menyebabkan mutu biji kakao masih rendah dan belum optimalnya pengembangan produk hilir kakao. Sedangkan permasalahan di sektor hilir sebagian besar disebabkan karena tingginya kandungan biji yang tidak difermentasi sehingga biji kakao Indonesia dikenakan automatic detention untuk pasar Amerika. Besarnya potongan harga akibat masalah tersebut pada tahun 2005 mencapai US $\$ 250 /$ ton (Askindo, 2005). Hal ini menjadi suatu tantangan sekaligus peluang bagi para investor untuk mengembangkan usaha dan meraih nilai tambah yang lebih besar dari agribisnis kakao.

Kakao dapat tumbuh sampai ketinggian tempat maksimum $1200 \mathrm{~m} \mathrm{dpl}$, namun ketinggian tempat optimum adalah 1-600 m dpl. Dengan demikian, Kabupaten Karo dapat dikembangkan tanaan kakao. Namun Luas dan produksi biji kakao selama tiga tahun terakhir terlihat stabil. Berdasar data statistik pada tabel 1.0 terlihat bahwa produksi biji kakao masih rendah yakni $\pm 600 \mathrm{~kg}$ per hektar. Kondisi ini masih sangat jauh dari potensi hasil yang dapat dicapai antara 50 - 120 buah/pohon/tahun atau setara dengan $2 \mathrm{~kg}$ biji kakao kering/pohon/tahun (Departemen Perindustrian, 2007).

Kecamatan Juhar merupakan salah satu wilayah pengembangan komoditas kakao yang terluas di Kabupaten Karo. Kecamatan Juhar berpenduduk jumlah sebanyak 4.719 $\mathrm{KK}$, dan luas wilayah 128,56 km2, yang berada pada ketinggian $630-1.030 \mathrm{~m}$ dpl. Tanaman Kakao merupakan salah satu komoditas unggulan yang dibudidayakan oleh petani di kecamatan Juhar. Untuk area pengembangan kakao, terletak di 25 desa dengan luas area tanaman kakao sebesar 1.142,96 ha atau sekitar 24 persen dari luas area kakao Kabupaten Karo, dengan produksi 783.06 ton/tahun. Hasil kunjungan di kebun petani menunjukkan bahwa rata-rata tanaman kakao belum dikelola dengan baik. Tingkat serangan hama dan penyakit yang tinggi menyebabkan rendahnya produksi biji kakao yang dihasilkan. Selain hama dan penyakit, umur tanaman juga menjadi salah satu penyebab produksi menurun. Rata-rata tanaman kakao petani sudah tua dengan usia tanaman kakao >15 tahun. Informasi tentang penerapan teknologi peremajaan tanaman kakao seperti sambung samping dan okulasi belum diterima oleh semua petani, sehingga tanaman kakao pada umumnya tumbuh tinggi $>4$ meter.

Konsekuensi dalam penerapan tekhnologi yang lebih maju merupakan peningkatan input dan peningkatan pengetahuan serta keterampilan baik dalam teknis produksi maupun kemampuan pengelolaan (manajemen). Agar tujuan akhir sesuai konsep 
agrobisnis yakni peningkatan pendapatan dapat tercapai. Pendapatan petani atau keuntungan dalam usahatani dapat diketahui melalui kegiatan analisa usahatani yang berguna untuk mengevaluasi tingkat keberhasilan suatu usahatani. Untuk merencanakan usahatani tanaman kakao dalam areal tertentu, dibutuhkan penyusuan rencana biaya maupuan manfaat yang akan didapatkan oleh petani dalam periode tertentu.

Selain sistem usahatani, pemasaran juga merupakan hal penting yang perlu diperhatikan dalam peningkatan pendapatan petani. Tersedianya pasar untuk hasil pertanian akan memudahkan petani untuk memasarkan hasil prosuksi pertaniannya. Sebab walaupun produksi dapat ditingkatkan, tetapi gagal dalam memasarkan hasil produksinya, maka sia-sialah usaha untuk meningkatkan produksi. Harga kakao yang mengalami perubahan setiap hari mengakibatkan petani menjual hasil produsksi biji kakao dengan mempertimbangkan strategi pasar yang tersedia, dengan harapan petani mendapatkan harga terbaik. Rantai pemasaran yang panjang dan luas sangat berpengaruh terhadap pendapatan petani. Rantai pasar yang panjang merupakan salah satu penyebab rendahnya keuntungan yang diterima oleh petani dalam setiap volume penjualan biji kakao. Sehingga dengan adanya persoalan ini, dibutuhkan kajian dan anlalisa yang lebih mendalam seberapa besar margin pemasaran biji kakao untuk setiap level pemasaran yang ada di wilayah Kecamatan Juhar Kabupaten Karo.

Pasar kakao di daerah penelitian bersifat oligopsoni. Informasi harga di tingkat eksportir/importir tidak diketahui dengan jelas, harga kakao bisa berubah dengan cepat dan cenderung fluktuatif menimbulkan ketidakpastian bagi petani. Dari uraian tersebut, masalah yang muncul yang perlu dijawab adalah bagaimana struktur dan saluran pemasaran, bagaimana efisiensi pasar serta berapa biaya, margin dan keuntungan pemasaran dari setiap lembaga pemasaran dibandingkan dengan proporsi harga yang diterima petani.

\section{METODE PENELITIAN}

Penelitian dilakukan di Desa Juhar Perangin-angin, Kidupen dan Juhar Ginting, Kecamatan Juhar Kabupaten Karo Provinsi Sumatera Utara dilakukan secara purposive sampling dengan pertimbangan bahwa kecamatan yang dipilih adalah lokasi sentra produksi (dari segi luas pertanaman, dan produksi). Penelitan ini akan dilakukan pada bulan Maret - April 2018 dengan metode quantitative research design yaitu metode survey dengan melaksanakan wawancara dan observasi kepetani dan pedagang. Pendekatan ini dilakukan untuk memperoleh data yang komprehensif dan saling melengkapi sehingga kondisi lapangan dapat dideskripsikan dengan baik

Pemilihan sampel desa dan kecamatan dilakukan dengan Sampling nonprobabilitas (nonprobability sampling), yaitu teknik sampling di mana tidak semua individu dalam populasi memiliki peluang yang sama untuk dipilih menjadi sampel. Sedangkan untuk penentuan responden dilakukan secara sengaja (purposive sampling), dengan pertimbangan bahwa tidak semua responden memiliki lahan $>0,5$ ha dengan jumlah pohon $>400$ pohon. Berdarkan informasi dari pemerintah desa lokasi penelitian, dari total kepala keluarga dari masing-masing desa, sekitar $80 \%$ adalah petani kakao. Dari total petani tersebut yang memiliki luas lahan $>0,5$ ha sekitar $30 \%$. Dari semua petani yang memiliki luas lahan berdasarkan kriteria tersebut diatas, diambil 10\% sampel responden secara representative untuk di observasi dan dilakukan wawancara. Total Petani yang akan diinterview sebanyak 36 orang petani yakni 12 petani per desa.

\section{Analisis Usahatani Kakao}


Analisis usahatani kakao meliputi rincian biaya, penerimaan dan pendapatan dalam usahatani kakao. Biaya usahatani (TC) adalah total biaya-biaya yang digunakan dalam proses usahatani kakao. Seperti biaya pembelian bibit, pupuk, pestisida, peralatan serta biaya tenaga kerja.

Penerimaaan merupakan penerimaan total produsen yang diperoleh dari hasil penjualn outputnya. Total penerimaan diperoleh dengan memperhitungkan output dikalikan harga jualnya. Penerimaan (TR) dapat juga diartikan banyaknya produksi total dikalikan dengan harga peneriamaan total diformulasikan sebagai berikut:

$\mathrm{TR}=\mathrm{P} \mathrm{X} \mathrm{Q}$

dimana:

TR $($ Total Revenue) $\quad=$ Total Penerimaan

$\mathrm{P}$ (Price) = Harga Produk (Rp)

$\mathrm{Q}$ (Quantity) = Jumlah Produk (Unit)

Analisis Pendapatan Usahatani Menurut (Hernanto, 1989), bertujuan untuk mengetahui besar keuntungan yang diperoleh dari usaha yang dilakukan. Untuk menghitung pendapatan usahatani dapat menggunakan rumus:

Pendapatan $(\pi)=$ TR - TC

Dimana:

TR $=$ Total Penerimaan

$\mathrm{TC}=$ Total pengeluaran

Dengan kriteria:

Jika TR>TC maka usahatani untung

Jika TR=TC maka usahatani impas atau tidak menguntungkan

Jika $\mathrm{TR}<\mathrm{TC}$ maka usahatani rugi

Kelayakan usahatani dapat diukur dengan berbagai cara, dan yang digunakan disini adalah dengan menghitung $\mathrm{R} / \mathrm{C}$ ratio, profit, perbandingan profit dengan modal (produktivitas modal), produktivitas tenaga kerja. Cara ini digunakan berkaitan dengan tujuan akhir yang akan dicapai oleh petani yaitu memperoleh pendapatan semaksimal mungkin (Soekartawi, 1995).

\section{Analisis Kelayakan Finansial}

Kelayakan usahatani dapat diukur dengan berbagai cara, dan yang digunakan di sini adalah dengan menghitung $B / C$ Ratio dan $R / C$ Ratio. Cara ini digunakan berkaitan dengan tujuan akhir yang akan dicapai oleh petani yaitu memperoleh pendapatan semaksimal mungkin (Soekartawi, 1995). Variabel biaya usahatani yang dikumpulkan meliputi biaya tetap dan variabel. Biaya tetap meliputi bibit dan tenaga kerja, sedangkan biaya variabel meliputi dan input (pupuk, pestisida dan bibit).

$\mathrm{B} / \mathrm{C}$ merupakan perbandingan antara pendapatan usahatani dengan biaya usahatani. B/C dapat juga didefenisikan sebagai tingkat keuntungan atau pendapatan yang diperoleh dengan total keseluruhan biaya yang dikeluarkan. Analisis B/C Ratio dapat dihitung dengan rumus :

$$
\mathrm{B} / \mathrm{C} \text { Ratio }=\frac{\text { Keuntungan }}{\text { Total Biaya Produksi }}
$$

Pada dasarnya suatu usaha dikatakan layak dan memberikan manfaat positif pada suatu usaha apabila nilai suatu B/C Ratio > 1 dan semakin besar suatu nilai B/C Ratio semakin besar pula manfaat positif yang akan diterima dalam suatu usaha tersebut (Rihardi, 2003).

Menurut Marrisa (2010), tingkat pendapatan usaha dapat diukur menggunakan alanisa penerimaan dan biaya (R/C Ratio) yang disarankan pada perhitungan secara finansial. Analisis ini menunjukkan besar penerimaan usaha yang akan diperoleh 
pengusaha untuk setiap rupiah biaya yang dipakai dalam kegiatan usahatani. J ika $\mathrm{R} / \mathrm{C}$ Ratio bernilai >1 maka usahatani menguntungkan. tertentu dapat memberikan nilai penerimaan sebagai manfaatnya. Analisis $\mathrm{R} / \mathrm{C}$ ratio merupakan perbandingan antara nilai output terhadap nilai inputnya atau perbandingan antara penerimaan dan pengeluaran usahatani. Untuk mengetahui nilai $\mathrm{R} / \mathrm{C}$ ratio dilakukan penghitungan dengan menggunakan rumus:

$$
\mathrm{R} / \mathrm{C} \text { Ratio }=\frac{\text { Jumlah Penerimaan }}{\text { Jumlah Biaya }}
$$

\section{Analisis Biaya Produksi}

Keseluruhan jumlah biaya produksi yang dikeluarkan dinamakan biaya total. Biaya produksi total atau total biaya didapat dari menjumlahkan biaya tetap total (total fixed cost) dan biaya variable total (total variable cost). Dengan demikian biaya total dapat dihitung dengan menggunakan rumus berikut:

$\mathrm{TC}=\mathrm{TFC}+\mathrm{TVC}$

Total Fixed Cost (TFC)

Keseluruhan biaya yang dikeluarkan untuk memperoleh faktor produksi (input) yang tidak dapat diubah jumlanya dinamakan biaya tetap total. Contoh biaya tetap adalah penyusutan peralataan usaha dan bibit yang dihitung menggunakan rumus sebagai berikut (Bambang dkk, 2011).

TFC $=$ TC - TVC

Total Variabel Cost (TVC)

Keseluruhan biaya yang dikeluarkan untuk memperoleh faktor produksi yang dapat diubah jumlahnya dinamakan biaya variable cost. Contoh biaya variable adalah biaya bahan baku. Pengertian Pendapatan Pendapatan merupakan salah satu indikator untuk mengukur kesejahteraan seseorang.

TVC $=$ TC-TFC

\section{Analisis Pemasaran}

Analisis pemasaran mengunakan sampel berupa pedagang kakao yang dipilih secara sengaja (purposive). Analisis pemasaran dilakukan secara deskriptif menggunakan berbagai analisis data sederhana dengan menggunakan perhitungan sederhana. Data berasal dari responden pedagang kakao dan hasil pengamatan selama berada di lokasi penelitian.

Marjin Pemasaran adalah perbedaan harga pada tingkat produsen (Pf) dengan harga di tingkat eceran atau konsumen (Pr) (Hasyim, 1994). Secara matematis perhitungan marjin dan profit marjin dirumuskan sebagai berikut:

$\mathrm{M}=\mathrm{Hj}-\mathrm{Hb}$

dimana:

$\mathrm{M}=$ Margin pemasaran setiap lembaga pemasaran (Rp/lembaga)

$\mathrm{Hj}=$ Harga jual setiap lembaga pemasaran $(\mathrm{Rp} / \mathrm{kg})$

$\mathrm{Hb}=$ Harga pembelian setiap lembaga pe-masaran $(\mathrm{Rp} / \mathrm{kg})$

Biaya dan Keuntungan Pemasaran

Berdasarkan hasil analisis biaya dan margin pemasaran, maka dapat dihitung keuntungan yang diterima oleh setiap pedagang yang terlibat dengan rumus:

dimana:

$$
\pi=\mathrm{M}-\mathrm{C}
$$

$\pi=$ Keuntungan setiap lembaga pemasaran (Rp)

$M=$ Margin pemasaran setiap lembaga pemasaran (Rp)

Efisiensi Pemasaran

$\mathrm{C}=$ Biaya yang dikeluarkan setiap lembaga pemasaran (Rp) Rasio Profit 
Pendekatan efisiensi operasional seringkali digunakan karena mempertimbangkan fungsi-fungsi yang mampu meningkatkan rasio output terhadap input pemasaran (Dilana, 2013). Analisis efisiensi pemasaran dengan pendekatan operasional diukur dengan marjin pemasaran, farmer's share dan rasio keuntungan terhadap biaya. Menghitung tingkat efisiensi pemasaran pada masing-masing saluran pemasaran menggunakan rumus efisiensi yaitu:

$$
\begin{aligned}
\mathrm{Ep}=\frac{\mathrm{TB}}{\mathrm{TNP}} \mathrm{X} 100 \% & \\
\text { dimana } & : \\
\mathrm{Ep} \quad & =\text { Efisiensi pemasaran; } \\
\mathrm{TB} & =\text { Total Biaya Pemasaran }(\mathrm{Rp}) ; \\
\mathrm{TNP} & =\text { Total Nilai Produk }(\mathrm{Rp})
\end{aligned}
$$

\section{HASIL DAN PEMBAHASAN}

Metode dasar yang digunakan untuk analisis usahatani adalah metode deskriptif (descriptive method). Melaui komponen tersebut dapat dibuat grafik biaya dan pendapatan dalam kegiatan usahatani. Grafik usahatani kakao dapat dilihat pada gambar 1.

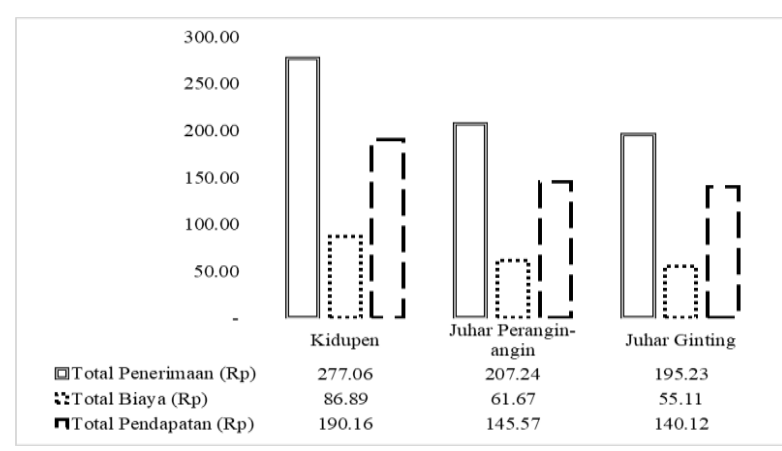

Gambar 1. Grafik Penerimaan, Biaya dan Pendapatan Usahatani Kakao

Dari hasil analisis pada Gambar 1 menunjukkan komponen biaya dan penerimaan di Desa Kidupen lebih tinggi dibandingkan Desa Juhar Perangin-angin dan Juhar Ginting. Biaya yang diguanakan dalam usahatani kakao meliputi biaya tetap (tenaga kerja), dan biaya variabel (pupuk dan pestisida/ Obat-obatan). Biaya bibit tidak dihitung, sebab bibit yang didapatkan oleh petani berasal dari pemerintah yang diberikan secara gratis. Ratarata petani menggunakan tenaga kerja untuk kegiatan pemangkasan, pemupukan, penyemprotan, pembersihan gulma dan panen. Alat yang digunakan untuk proses tersebut disediakan sendiri oleh pekerja. Untuk menghitung besarnya pencurahan tenaga kerja dari setiap jenis tenaga kerja yang digunakan, dikonversikan ke dalam Hari Orang Kerja (HOK). Upah tenaga kerja didaerah penelitian sebesar Rp.70.000,- per hari.

Total produksi kakao yang dihasilkan Desa Kidupen sebesar $11.082 \mathrm{~kg}$ dengan luas lahan 10,7 ha, Desa Juhar Perangin-angin $8.290 \mathrm{~kg}$ dengan luas lahan 8,2 ha, dan Juhar Ginting $7.809 \mathrm{~kg}$ dengan luas lahan 7,7 ha. Total penerimaan yang dihasilkan oleh masing-masing desa adalah sebesar Rp. 277.060.000; Rp.207;240.000; 195.230.000. Sedangkan total pendapatan masing-masing desa adalah sebear Rp.190.160.000; Rp.145.570.000; Rp.140.120.000. Dari hasil tersebut dapat diketahui jumlah ata-rata pendapatan per petani di masing-masing desa per bulan yakni sebesar Rp.1.320.574; Rp.1.010.911; Rp.973.056

Dengan demikian dapat disimpulkan bahwa pendapatan petani terbesar diterima oleh petani Desa Kidupen, diikuti petani Juhar Perangin-angin dan Juhar Ginting. 
Kondisi ini disebabkan oleh produksi yang dihasilkan, luas lahan dan jumlah pohon yang dimiliki Desa Kidupen lebih tinggi dibandingkan dua desa lainnya dengan jumlah responden yang sama ditiap desa. Data tabel usahatanai kakao dapat dilihat pada daftar lampiran 2,3,4.

Hasil analisis usahatani kakao sesuai Lampiran 5 menunjukkan bahwa nilai B/C ratio untuk Desa Kidupen, Juhar Perangin-angin dan Juhar Ginting masing - masing sebesar 2,$19 ; 2,36 ; 2,54$. Berdasarkan data tersebut dapat disimpulkan bahwa nilai B/C untuk ketiga desa $>1$, artinya usahatani dianggap layak untuk diusahakan karena dapat memberikan keuntungan. Hal ini terjadi tanaman kakao diberikan pupuk NPK, dan sebgian petani menambahkan pupuk kompos pada tanaman kakao. Dosis pupuk yang diberikan yakni sekitar \pm 600 gram per pohon per tahun dan sesuai standart yang direkomendasikan untuk tanamank kakao.

Hasil analisis usahtani kakao dapat diketahui bahwa nila $\mathrm{R} / \mathrm{C}$ ratio untuk Desa Kidupen, Juhar Perangin-angin dan Juhar Ginting masing - masing sebesar 3,91; 3,36 ; 3,54. Berdasarkan data tersebut dapat disimpulkan bahwa nilai R/C untuk tiga desa tersebut $>1$, artinya usahatani tersebut dapat disahakan dan memberikan keuntungan bagi petani.

\section{Analisis Biaya Produksi}

Biaya produksi meliputi biaya tetap dan biaya variabel. Yang termasuk Fix Cost (FC) dalam usahatani ini adalah biaya tenaga kerja Sedangkan Variabel Cost (VC) adalah biaya pupuk dan biaya pestisda/obat-obatan. Sedangkan Total Cost (TC) adalah hasil penjumlahan antara TC dan VC. Hasil analisis biaya produksi dapat dilihat dalam Lampiran 7. Secara grafik dapat dilihat dalam gambar 2 dibawah.

$\rightarrow$ - Kidupen $\quad-\quad$ Juhar Perangin-angin $\quad \cdots \mathbf{l} \cdot$... Juhar Ginting

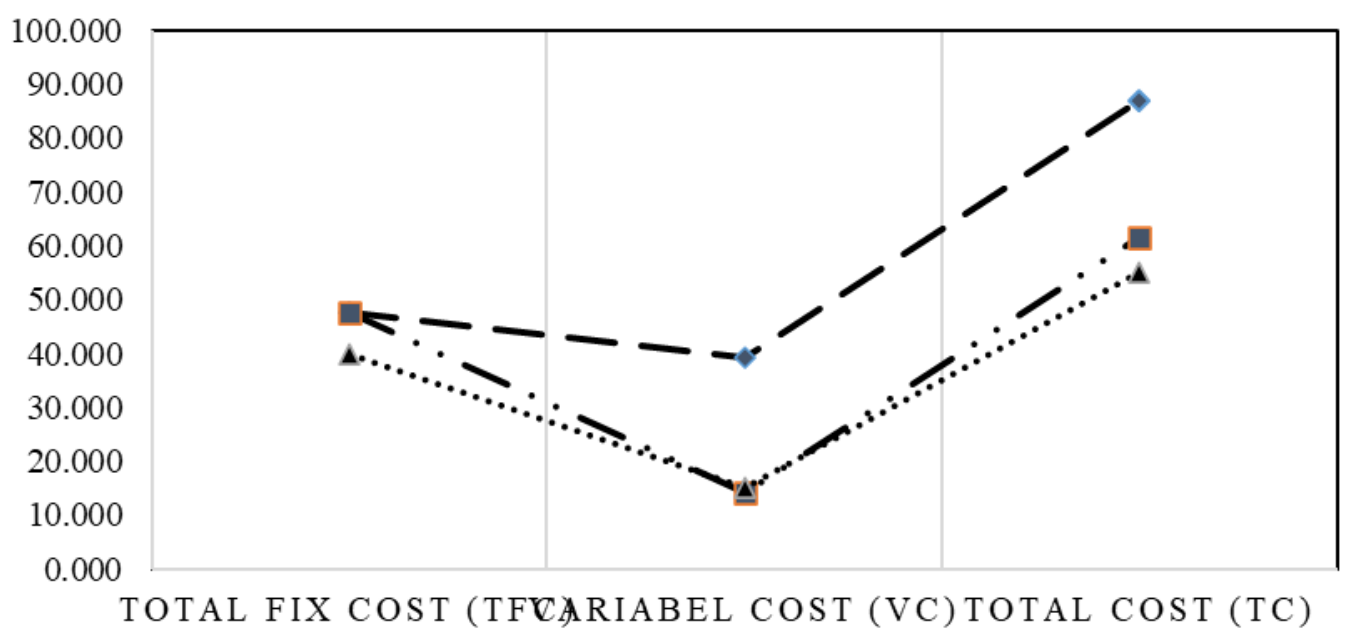

Gambar 2. Grafik Hasil Analisis Biaya Produksi

Berdasarkan gambar 2 menunjukkan total biaya tetap (TFC) yang dikeluarkan per tahun sebesar Rp.135.048.000, biaya variabel (VC) sebesar Rp.68.623.000,- sehingga biaya total sebesar Rp. 203.671.000. Biaya produksi tertinggi adalah TFC yakni tenaga kerja dengan persentase sebesar 66\%. Hal ini disebabkan karena responden tidak hanya mengandalkan tenaga kerja dari dalam keluarga tetapi juga mengandalkan tenaga kerja 
dari luar keluarga atau menyewa orang lain, sehingga harus mengeluarkan biaya untuk memberi upah kerja kepada pekerja atau buru tani.

\section{Saluran Pemasaran}

Sasaran pengembangan yang ingin dicapai dalam pemasaran biji kakao adalah peningkatan kualitas dan kuantitas biji kakao yang dihasilkan oleh petani. Hingga saat ini implemntasi fermentasi biji kakao untuk mendapatkan kualitas biji kakao yang baik belum dapat direpakan oleh petani. Hal ini disebabkan oleh kesadaran petani untuk menghasilkan biji kakao yang berkualitas masih sangat rendah karena masalah ekonomi akibat desakan kebutuhan rumah tangga mendesak yang menuntut penjualan hasil panen dilakukan secepat mungkin. Rantai pemasaran yang panjang juga memperngaruhi pendapatan petani. Hasil diskusi dan penelusuran jalur distribusi biji kakao di Kecamatan Juhar secara singkat ditampilkan pada gambar dibawah.

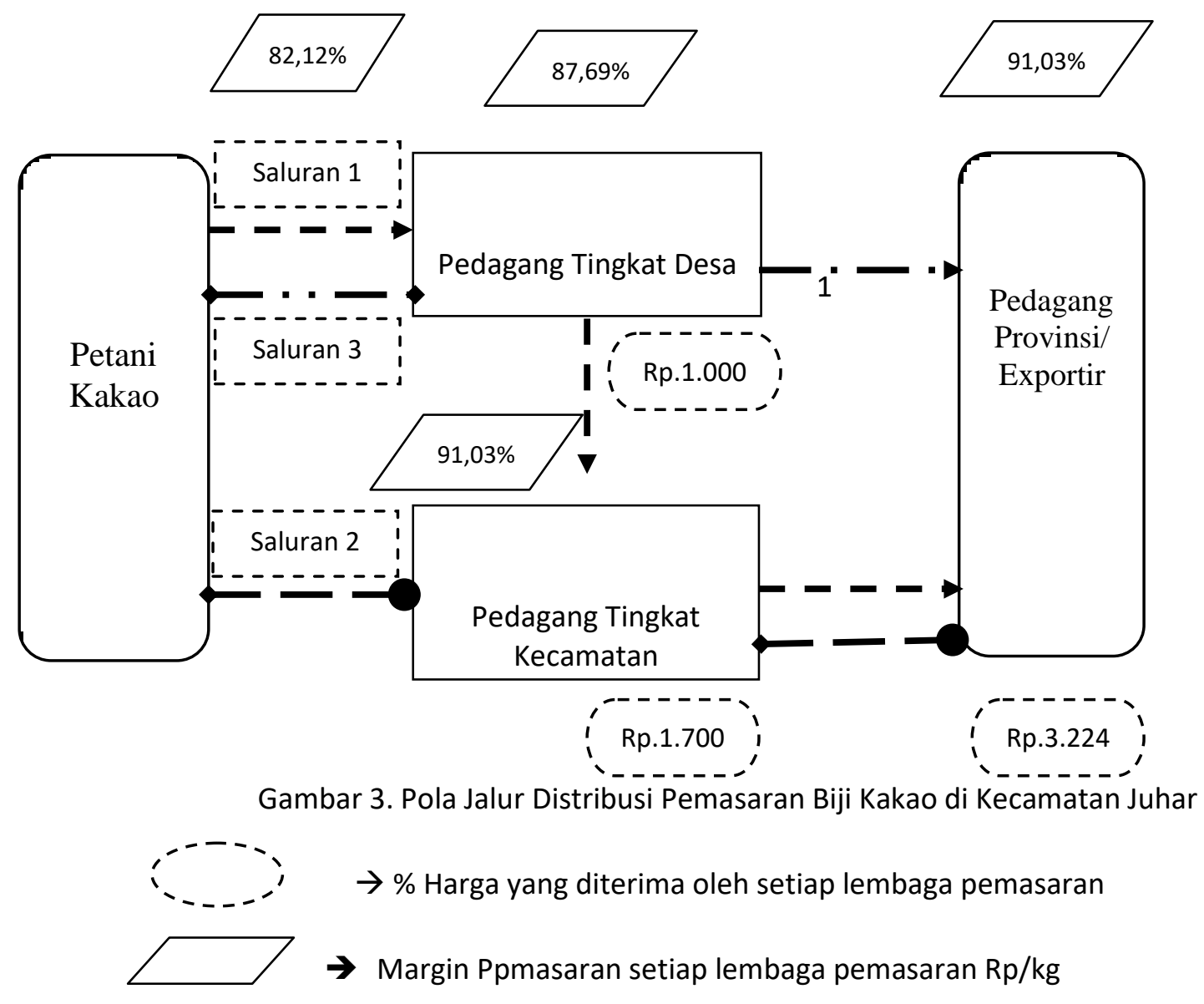

Lembaga pemasaran yang terlibat dalam saluran pemasaran kakao di lokasi penelitian adalah: petani, pedagang desa, pedagang kecamatan, dan pedagang provinsi/eksportir. Berdasarkan skema pola jalur distribusi biji kakao, terdapat tiga pola saluran yang terbentuk pada aktifitas perdagangan biji kakao di Kecamatan Juhar yaitu:

Saluran $1 \rightarrow$ Petani Kakao $\rightarrow$ Pedagang Pengumpul Desa $\rightarrow$ Pedagang Pengumpul Kecamatan $\rightarrow$ Pedagang Pengumpul Provinsi.

Saluran $2 \rightarrow$ Petani Kakao $\rightarrow$ Pedagang Pengumpul Kecamatan $\rightarrow$ Pedagang Pengumpul Provinsi.

Saluran $3 \rightarrow$ Petani Kakao $\rightarrow$ Pedagang Pengumpul Provinsi/Exportir 
Ketiga pola saluran pemasaran tersebut dijadikan standar dalam perhitungan efisiensi pasar atas distribusi biji kakao pada setiap lembaga pemasaran yang terlibat dan saluran pemasaran yang terbentuk. Biaya pemasaran kakao adalah biaya yang dikeluarkan dalam proses pergerakan biji kakao dari petani kakao yang dihitung mulai dari tingkat desa hingga tingkat provinsi. Biaya pemasaran yang dikeluarkan oleh setiap tingkatan pedagang berbeda - beda berdasarkan jenis biaya yang dikeluarkan dalam setiap penjualan biji kakao.

\section{Biaya dan Keuntungan Pemasaran}

Biaya pemasaran yang digunakan setiap tingkat pedagang berbeda-beda. Biaya yang digunakan oleh setiap pedangan meliputi tenaga kerja, karung, penyesuain biji menjadi standart SNI, transportasi dan bongkar muat. Keuntungan yang diperoleh setiap pedagang juga berbeda-beda, tergantung harga yang diperoleh oleh setiap tingkat pedagang dan jumlah biaya pemasaran yang dikeluarkan. Keuntungan pemasaran dianalisis berdasarkan margin dan biaya pemasaran pada masing-masing lembaga pemasaran.Analisis keuntungan pemasaran dapat dilihat pada Tabel 1.

Tabel 1. Analisis Biaya dan Keuntungan Pemasaran Biji Kakao.

\begin{tabular}{|c|c|c|c|}
\hline No & Lembaga Pemasaran & $\begin{array}{c}\text { Biaya } \\
\text { Pemasaran }\end{array}$ & $\begin{array}{c}\begin{array}{c}\text { Keutungan } \\
\text { Pemasaran }\end{array} \\
(\mathrm{Rp} / \mathrm{Kg})\end{array}$ \\
\hline \multicolumn{4}{|c|}{ Saluran I } \\
\hline 1 & Pedagang Pengumpul Desa & 585 & 415 \\
\hline 2 & Pedagang Pengumpul Kecamatan & 931 & 769 \\
\hline \multirow[t]{2}{*}{3} & Pedagang Pengumpul Provinsi/Exportir & 822 & 2.402 \\
\hline & Total & 2.338 & 3.586 \\
\hline \multicolumn{4}{|c|}{ Saluran II } \\
\hline 1 & Pedagang Pengumpul Kecamatan & 931 & 769 \\
\hline \multirow[t]{2}{*}{2} & Pedagang Pengumpul Provinsi/Exportir & 822 & 2.402 \\
\hline & Total & 1.753 & 3.171 \\
\hline \multicolumn{4}{|c|}{ Saluran III } \\
\hline 1 & Pedagang Pengumpul Desa & 585 & 415 \\
\hline \multirow[t]{2}{*}{2} & Pedagang Pengumpul Provinsi/Exportir & 822 & 2.402 \\
\hline & Total & 1.407 & 2.817 \\
\hline
\end{tabular}

Sumber : Data Primer (diolah), 2017

Berdasarkan tabel 1 menunjukkan bahwa biaya yang dikeluarkan terbesar oleh pedagang tingkat kecamatan sebesar RP 931, diikuti pedagang tingkat provinsi sebesar Rp 822 dan pedagang tingkat desa sebesar Rp 585. Sedangkan keuntungan berdasarkan tabel menunjukan bahwa pedagang tingkat provinsi merupakan penerima keuntungan terbesar yakni Rp.2.402, diikuti oleh pedagang tingkat kecamatan sebesar Rp.769 dan pedagang tingkat desa sebesar Rp.415.

Keuntungan pemasaran pada saluran I, II dan III masing-masing adalah sebesar Rp.3.586; Rp.3.171; Rp.2.817. Saluran pemasaran I mendapatkan keuntungan terbesar dari saluran pemasaran yang lainnya. Keuntungan dipengaruhi oleh biaya yang 
dikeluarkan oleh setiap lembaga pemasaran. Semakin panjang saluran pemasaran keuntungan yang diperoleh semakin tinggi. Penelitian yang dilakukan oleh Darwis Ali menunjukkan hasil yang sama, bahwa keuntungan pemasaran yang terbesar berada pada Saluran I yakni sebesar Rp. 7.006,18 yang merupakan saluran terpanjang dalam distribusi biji kakao di Sulawesi Selatan. Semakin pendek saluran pemasaran biji kakao, maka semakin kecil total keuntungan pemasarannya.

\section{Margin Pemasaran}

Tingkat margin untuk setiap pedagang pada setiap saluran yang terbentuk juga bervariasi. Margin pemasaran adalah perbedaan harga yang dibayar kepada penjual pertama dan harga yang dibayar oleh pembeli terakhir. Secara teoritis, faktor-faktor yang mempengaruhi besarnya margin pemasaran adalah: (1) Biaya pemasaran, keuntungan dari perantara dan harga produsen; (2) Sifat barang yang diperdagangkan; dan (3) Tingkat pengolahan barang yang dipasarkan.

Besarnya margin pemasaran didasarkan atas tingkat harga beli biji kakao kering. Pedagang provinsi membeli biji kakao kering dari pedagang kecamatan/kabupaten sebesar Rp.32.700 per kilo gram. Pedagang tingkat kecamatan membeli dari pedagang level desa atau dari petani sebesar Rp 31.000 per kilo gram. Sedangkan pedagang tingkat desa membeli dari petani yang menjadi harga ditingkat desa adalah Rp.29.500 per kilo gram. Harga kakao dunia berdasarkan harga pasar yang berlaku pada hari tersebut sebesar US\$ 2.556 per ton atau US\$ 2,55 per kilo gram pada kurs per US\$ 1 sebesar Rp 14.055, maka harga kakao setara dengan Rp 35.924 per kilo gram. Analisis margin pemasaran dapat dilihat pada tabel 2.

Tabel 2. Analisisi Margin Pemasaran Biji Kakao

\begin{tabular}{|c|c|c|}
\hline No & Lembaga Pemasaran & $\begin{array}{c}\begin{array}{c}\text { Margin } \\
\text { Pemasaran }\end{array} \\
(\mathrm{Rp} / \mathrm{Kg}) \\
\end{array}$ \\
\hline \multicolumn{3}{|c|}{ Saluran I } \\
\hline 1 & Pedagang Pengumpul Desa & 1.000 \\
\hline 2 & Pedagang Pengumpul Kecamatan & 1.700 \\
\hline 3 & Pedagang Pengumpul Provinsi/Exportir & 3.224 \\
\hline & Total & 5.924 \\
\hline \multicolumn{3}{|c|}{ Saluran II } \\
\hline 1 & Pedagang Pengumpul Kecamatan & 1.700 \\
\hline 2 & Pedagang Pengumpul Provinsi/Exportir & 3.224 \\
\hline & Total & 4.924 \\
\hline \multicolumn{3}{|c|}{ Saluran III } \\
\hline 1 & Pedagang Pengumpul Desa & 1.000 \\
\hline 2 & Pedagang Pengumpul Provinsi/Exportir & 3.224 \\
\hline & Total & 4.224 \\
\hline
\end{tabular}

Sumber : Data Primer (diolah), 2017 
Berdasarkan analisis margin pemasaran biji kakao pada Tabel 8 dapat diketahui bahwa dari seluruh komponen biaya yang dikeluarkan oleh pedagang, biaya penyesuaian standar mutu merupakan unsur biaya yang terbesar pada semua tingkatan. Hal ini tejadi sebab standart mutu yang dijual oleh setiap pedagang belum sesuai SNI. Berdasarkan hasil diskusi dengan pedagang tingkat desa dan kecamatan, dalam pembelian biji kakao, standart mutu yang diberlakukan kepada petani hanya kadar air. Rata-rata kadar air yang dibeli dari petani adalah kadar air 10\%. Standart mutu kakao berdasarkan Standart Nasional Indonesia (SNI) yang diterapkan oleh pedagang adalah kadar air 8\%, Sampah 3\%, Jumlah biji/100 gram 110 biji, dan jamur 5\%.

Karakteristik perolehan keuntungan di tingkat pedagang pada pemasaran biji kakao adalah tidak dengan menurunkan harga pada saat pembelian, tetapi keuntungan diperoleh dari kompensasi penyesuaian standar mutu (kadar air, jamur dan kotoran). Adanya kesamaan pembiayaan pada setiap lembaga pemasaran karena lokasi pembelian tidak terlalu jauh dan kecenderungan terbentuk kesamaan pembiayaan karena arus informasi harga yang berlaku sangat lancar dari pembeli dan penjual setiap hari. Berdasarkan data diatas menunjukkan biaya pemasaran terbesar terjadi pada pedagang pengumpul tingkat kecamatan, dan biaya terbesar adalah biaya penyesuaian standrt dan transportasi. Hal ini terjadi karena biji kakao yang diterima dari pedagang di tingkat desa tidak sesuai dengan standart. Penyesuain mutu dilakukan oleh pedagang kecamtana dehingga dibutuhkan tenaga kerja dalam melakukan proses biji kakao menjadi standart.

Hasil penelitian menunjukkan bahwa margin terbesar diperoleh lembaga pemasaran Provinsi/eksportir yang mencapai Rp 3.824 per $\mathrm{kg}$, selanjutnya pedagang tingkat kecamatan Rp.1.700 per kg dan pedagang tingkat desa Rp.1.000 per kg. Hal ini menunjukkan bahwa semakin jauh sentra produksi, cenderung semakin kecil margin pemasaran yang diterima pedagang, Keuntungan pemasaran adalah selisih antara penerimaan margin pemasaran dikurangi dengan biaya pemasaran. Semakin besar margin, semakin besar juga biaya. Perlu pembahasan.

Hasil penelitian yang dilakukan oleh I Made Beni Andana, S.P volume 5 menunjukkan bahwa marjin pemasaran pada saluran pemasaran satu adalah sebesar Rp. 10.500 dengan biaya yang timbul pada lembaga pemasaran pedagang pengumpul sebesar Rp. 1.300 dan pada pedagang besar Rp. 1.100. Marjin pemasaran pada saluran pemasaran dua adalah Rp. 5.500 dengan biaya yang timbul pada petani produsen sebesar Rp. 1.400 dan pada pedagang besar Rp. 1.100. Nilai farmer's share sebesar 63,16 \%, sedangkan pada saluran pemasaran II sebesar 80,7 \%. Semakin besar bagian harga yang diterima oleh petani, dapat dikatakan bahwa saluran pemasaran tersebut semakin efisien. Dengan demikian maka saluran pemasaran yang paling efisien adalah saluran pemasaran II.

\section{Efisiensi Pemasaran}

Efisiensi pasar adalah ukuran dari persentase perbandingan antara biaya pemasaran dengan nilai produk yang dipasarkan. Semakin rendah angka persentase efisiensi pasar, maka semakin tinggi efisiensinya. Suatu kegiatan pemasaran dikatakan tidak efisien jika biaya pemasaran semakin besar dan nilai produk yang dipasarkan jumlahnya sedikit. 
Berdasarkam analisis efisiensi pasar menunjukkan bahwa saluran pemasaran III merupakan saluran pemasaran yang paling efisien yakni 0,042\%, dimana saluran pemasaran tersebut melibatkan pedagang pengumpul desa dan pedagang provinsi/eksportir, diikuti saluran pemasaran II yakni 0,052\% dan saluran pemasaran I yakni $0,071 \%$. Efisiensi pemasaran dapat terjadi yaitu jika (1) Biaya pemasaran dapat ditekan sehingga keuntungan pemasaran menjadi lebih tinggi; (2) tersedia fasilitas fisik pemasaran; (3) adanya kompetisi pasar yang sehat. Analisis efeisiensi pemasaran biji kakao dapat dilihat pada tabel 3.

Tabel 3. Analisis Efisiensi Pemasaran Biji Kakao

\begin{tabular}{|c|c|c|}
\hline No & Lembaga Pemasaran & $\begin{array}{c}\begin{array}{c}\text { Efisiensi } \\
\text { Pemasaran }\end{array} \\
\%)\end{array}$ \\
\hline \multicolumn{3}{|c|}{ Saluran I } \\
\hline 1 & Pedagang Pengumpul Desa & 0,019 \\
\hline 2 & Pedagang Pengumpul Kecamatan & 0,029 \\
\hline 3 & Pedagang Pengumpul Provinsi/Exportir & 0,023 \\
\hline & Total & 0,071 \\
\hline \multicolumn{3}{|c|}{ Saluran II } \\
\hline 1 & Pedagang Pengumpul Kecamatan & 0,029 \\
\hline 2 & Pedagang Pengumpul Provinsi/Exportir & 0,023 \\
\hline & Total & 0,052 \\
\hline \multicolumn{3}{|c|}{ Saluran III } \\
\hline 1 & Pedagang Pengumpul Desa & 0,019 \\
\hline 2 & Pedagang Pengumpul Provinsi/Exportir & 0,023 \\
\hline & Total & 0,042 \\
\hline
\end{tabular}

Sumber : Data Primer (diolah), 2017

Hasil penelitian yang dilakukan oleh Nike Salfida KaroKaro, dkk, menunjukkan hasil yang sama. Untuk saluran pemasaran I, efisiensi Pemasaran saluran I adalah 8.2\%. Untuk saluran pemasaran II, 6.2\%. Dari nilai efisiensi yang diperoleh diketahui bahwa saluran II lebih efisien dibandingkan dengan saluran I. Saluran pemasaran dikatakan efisien bila mampu mendistribusikan hasil produksi kepada konsumen dengan biaya semurahmurahnya dan mampu membagi keuntungan yang adil kepada semua pihak yang ikut serta didalam kegiatan produksi dan pemasaran.

\section{SIMPULAN}

Hasil analisis usahatani Desa Kidupen menunjukkan bahwa pendapatan tertinggi diperoleh Desa Kidupen, diikuti oleh dua desa lainnya. Kelayakan Finansial di Desa Kidupen, Juhar Perangin-angin dan Juhar Ginting memiliki nilai B/C ratio dan R/C > 1 , hal ini menunjukkan usahatani tersebut layak untuk diusahakan. Biaya Produksi meliputi biaya tetap (TFC) dan biaya variabel (VC). Biaya produksi tertinggi adalah TFC yakni tenaga kerja, dengan persentase sebesar $66,3 \%$. Tingkat pendapatan yang diperoleh petani dari hasil usahatani kakao tergolong sedang jika dibandingkan dengan Upah Minimum Regional (UMR 2017) untuk Kabupaten Karo sebesar Rp.2.383.500 per bulan, sedangkan rata-rata pendapatan petani kurang dari nilai tersebut yakni sebesar Rp.1.101.500. 
Hasil Analisis Pemasaran menunjukkan hasil sebagai berikut terdapat tiga tipe saluran pemasaran biji kakao di Kecamatan Juhar. Saluran pemasaran tersebuta adalah a) saluran pemasaran 1 yaitu petani $\rightarrow$ pedagang tingkat desa $\rightarrow$ pedagang kecamatan $\rightarrow$ pedagang provinsi; b) saluran pemasaran II yaitu petani $\rightarrow$ pedagang tingkat kecamatan $\rightarrow$ pedagang provinsi, dan c) saluran pemasaran III yaitu petani $\rightarrow$ pedagang tingkat desa $\rightarrow$ pedagang tingkat provinsi. Sistem pemasaran yang paling efisien adalah pada saluran pemasaran 3 dengan efisiensi sebesar 0,042 persen, diikuti saluran pemasaran 2 dengan efisiensi sebesar 0,052 persen dan larulan pemasaran 3 dengan efisiensi sebesar 0,071 persen. Artinya semakin panjang saluran pemasaran, maka semakin tidak efisien sistem pemasaran tersebut, hal ini disebabkan karena biaya yang digunakan dalam pemasaran semakin tinggi.

\section{DAFTAR PUSTAKA}

Asosiasi Kakao Indonesia. 2005. Prospek Agroindustri Kakao Indonesia di Pasaran Dunia

Assauri Sofjan. 2008. Manajemen Produksi dan Operasi, Jakarta. Fakultas Ekonomi. Universita Indonesa.

Dilana, I.A. (2013). Pemasaran dan nilai tambah biji kakao di Kabupaten Madiun Jawa Timur. (Tesis Magister Sains, Sekolah Pascasarjana, Institut Pertanian Bogor, Bogor)

Fandy Tjiptono, 2008. Strategi Pemasaran CV. Andi Offset, Jakarta.

Goenadi, didiek. H, John Bako Baon, Herman Adreng Purwanto, 2005. Prospek dan Arah.

Hanafiah, dan Saenuddin. 2006. Tataniaga Hasil Pertanian. Jakarta: Universitas Indonesia Press.

Hernanto, F. 1993. Ilmu Usahatani. Cetakan Ketiga (Jakarta: Penebar Swadaya).

Janie, D.N.A., 2012, Statistik Deskriptif \& Regresi Linear Berganda Dengan SPSS, Cetakan Pertama, Semarang University Press

Kotler dan Kevin, 2012. " Marketing Management “ 19th editon, USA. Prentice Hall

Kotler dan Amstrong, 2012. "Principles of Marketing" 14th edition. Ne Jersey: Pearson Prentice Hall.

Kotler. 2002. Manajemen Pemasaran. Jilid 1. Edisi Kesepuluh. PT Prenhalindo. Jakarta

Kotler , P. 1997. Manajemen Pemasaran Analisis, Perencanaan, Implementasi Dan Kontrol. PT Prenhallindo: Jakarta

Laporan Departemen Perdagangan, 2007. Gambaran Sekilas Indutri Kakao. http//www.deperin.go.id

Marissa.2010. Model Pembelajaran Science Technology Society. Makalah pada Sekolah Pasca Sarjana, UPI.

Nasruddin, W. 1996. Tataniaga Pertanian. Universitas Terbuka: Jakarta

Neuman WL. 2003. Social Research Methods Fifith edition. United States of America: Pearson Education, Inc.

Pengembangan Agribisnis Kakao di Indonesia.Jakarta. Di Akses dari www.litbangdeptan.co.id. Dalam www.google.com. Tanggal 3 Juni 2015

Peluang Usaha Budidaya Kakao, Bisa Panen Tiap Hari, 2014. http://wartawirausaha.com/2014/08/peluang-usaha-budidaya-kakao-bisa-panen-tiaphari/\#ixzz59VHvzWDX

Rahim, Dwi Retno dan Hastuti Abd, 2007, Ekonomika Pertanian. Jakarta: Rajawali Pers

Rahmat Rukmana \& H. Herdi Yudirachman.2016. Untung Selangit dari Agribisnis Kakao. Jakarta.

Ratya Anindita, dkk. 2017. Pemasaran Produk Pertanian. Penerbit Andi, Jakarta.

Razali, N.M., Yap Bee Wah. 2011. Power Comparision of Shapiro-Wilk, KolmogorovSmirnov, Lilliefors, and Anderson-Darling tests. Journal of Statistical modeling and Analytics Volume 2 No. 1. 21-33

Rihardi, F. Palungkun, Rony. Budiarti, Asiani. 1993. Agribisnis Tanaman Sayuran. (Jakarta:

Salikin, AK. 2003. Sistem Pertanian Berkelanjutan. Kanisius, Yokjakarta.

Shinta. 2011. Ilmu Usahatani. Penerbit Universitas Brawijaya Press. Malang

Soeharjo dan Patong. 1991. Ilmu Usahatani. Bogor. Departemen Ilmu Sosial Ekonomi

Soeharto, Iman. 1993. Manajemen Proyek: Dari Konseptual Sampai Operasional, Erlangga. Jakarta

Soekartawi, 2002. Prinsip Ekonomi Pertanian. PT. Raja Grafindo Persada, Jakarta

Soekartawi , 2000. Pembangunan Pertanian, Rajawali Press, Jakarta

Sudiyono. 2002. Pemasaran Pertanian. Universitas Muhammadiyah Malang.

Sudjana, 1992, Metode Statistik. Tarsito, Bandung

Sujiwo, Joko Tri. 2009. Efisiensi Pemasaran Kopi (Coffea Sp) Di Kecamatan Singorojo

Kabupaten Kendal Semarang. Jurnal. Universitas Wahid Hasyim: Semarang.

Sukirno, Sadono. 2006. Pengantar Mikro Ekonomi. Edisi Kedua. Jakarta: PT Raja Grafindo Persada.

Swasta dan Irawan 1990. Managemen Pemasarn Modern Edisi 2. Jakarta 